\title{
PENGARUH BAURAN PEMASARAN 7P TERHADAP PERSEPSI KONSUMEN PT HOME CREDIT INDONESIA
}

\section{THE EFFECT OF MARKETING MIX (7P) ON CONSUMER PERCEPTION OF PT HOME CREDIT INDONESIA}

\author{
Ika Novi Indriyati ${ }^{*}$, Arief Daryanto ${ }^{* *}$, dan Rina Oktaviani ${ }^{* * *}$ ) \\ *) Wellstead Corporate Solutions Pte Ltd \\ Level 26 PSA Building 460 Alexandra Road Singapore 119963 \\ ${ }^{* *}$ Sekolah Bisnis, Institut Pertanian Bogor \\ Jl. Raya Pajajaran, Bogor 16151 \\ ${ }^{* * *}$ Departemen Ilmu Ekonomi, Fakultas Ekonomi dan Manajemen, Institut Pertanian Bogor \\ Jl. Agatis Kampus IPB Darmaga, Bogor 16680
}

\begin{abstract}
The happier the customers in using the payments through the system of financing, the more intense the competition has become among finance companies. Therefore, the management needs to consider the factors of marketing mix to determine the appropriate sales strategy. This research aimed to comprehend and analyze the marketing mix and its effect on consumer perceptions, and develop appropriate marketing mix strategy in affecting consumers. The method used in this research was linear regression analysis by using software. The primary data used were collected using Likert scale questionnaire. The results of this research showed the marketing mix variables affecting consumer perception included. the variables of location and convenience. Both affecting variables are referenced to assist consumers and increase their satisfaction and comfort.
\end{abstract}

Keywords: costumer perception, costumer satisfaction, marketing mix, perception, strategy

Abstrak: Seiring dengan semakinbanyak konsumenyang senang menggunakankemudahan pembayaran melalui sistem pembiayaan, semakin ketat pula persaingan perusahaanperusahaan pembiayaan sehingga penting untuk manajemen untuk mempertimbangkan faktor-faktor bauran pemasaran dalam rangka menentukan strategi penjualan yang tepat. Penelitian ini bertujuan untuk memahami dan menganalisis tentang bauran pemasaran dan pengaruhnya terhadap persepsi konsumen serta mengembangkan strategi bauran pemasaran yang tepat dalam memengaruhi konsumen. Metode yang digunakan adalah analisis regresi linier dengan menggunakan perangkat lunak. Data yang digunakan adalah data primer dengan pengumpulan datanya lewat kuesioner berskala Likert. Hasil penelitian menunjukkan bahwa variabel bauran pemasaran, yang memengaruhi persepsi konsumen adalah variabel lokasi dan kenyamanan. Kedua variabel berpengaruh ini dirujuk dalam rangka memudahkan konsumen dan peningkatan kepuasan dan kenyamanan konsumen.

Kata kunci: bauran pemasaran, kepuasan konsumen, persepsi konsumen, persepsi, strategi

${ }^{1}$ Alamat Korespondensi:

Email: ikanovi9@gmail.com 


\section{PENDAHULUAN}

Seiring dengan berkembangnya roda perekonomian, maka kebutuhan juga meningkat, khususnya kebutuhan di bidang jasa (Rahayu et al. 2015). Changchit (2006) berpendapat: "Consumers can shop at anytime and have access to products not available in their geographic region " yang artinya bahwa konsumen dapat berbelanja produk yang tidak tersedia di daerahnya kapan saja. Konsumen yang mempunyai penghasilan terbatas biasanya membeli barang keinginan dan kebutuhannya dengan cara kredit atau dibiayai oleh sebuah lembaga keuangan baik bank atau non bank. Seiring semakin banyak konsumen yang senang menggunakan kemudahan pembayaran dalam sistem pembiayaan, berbagai lembaga keuangan baik bank ataupun non bank telah hadir untuk memudahkan perencanaan finansial, dalam pembelian barang secara non tunai. Dalam persaingan yang semakin ketat, perusahaan tidak hanya dapat mengandalkan peningkatan mutu dan pengembangan produk jasa semata, walaupun berkualitasnya suatu produk, bila konsumen belum pernah mengetahuinya dan tidak yakin kalau produk tersebut akan berguna bagi mereka, maka mereka tidak akan pernah membelinya (Putri, 2011).

PT. Home Credit Indonesia adalah salah satu dari 201 perusahaan pembiayaan yang terdaftar dalam direktori industri keuangan non bank yang di keluarkan OJK pada tahun 2015. Dari Forum Group Discussion (FGD) dengan pihak manajemen perusahaan, dapat diketahui bahwa faktor-faktor yang tergabung dalam bauran pemasaran mempunyai pengaruh penting dalam penjualan jasa.

Tujuan penelitian adalah untuk memahami dan menganalisis tentang bauran pemasaran dan pengaruhnya terhadap persepsi konsumen serta mengetahui bauran pemasaran yang tepat. Variabel penelitian adalah bauran pemasaran 7P, yaitu produk, harga, lokasi, promosi, SDM, proses dan penampilan fisik yang akan diteliti apakah variabel-variabel tersebut berpengaruh secara parsial maupn simultan terhadap persepsi konsumen.

Penelitian ini berfokus pada aspek bauran pemasaran 7P dan persepsi konsumen. Objek penelitian adalah konsumen yang sudah pernah atau sedang mendapatkan pembiayaan dari PT. Home Credit Indonesia. Untuk meningkatkan volume atau jumlah penjualan dari suatu produk yang ditawarkan maka tidak bisa terlepas dari aktivitas pemasaran (Heryanto, 2015). Dalam pemasaran, perusahaan harus menciptakan langkahlangkah yang tepat berupa strategi yang disusun berdasarkan faktor-faktor dari bauran pemasaran. Menurut Booms dan Bitner yang dikutif oleh Tjiptono dan Gregorius (2012) menyatakan bahwa konsep bauran pemasaran tradisional (tradisional marketing mix) terdiri dari 4P, yaitu produk (product), harga (price), tempat/lokasi (place) dan promosi (promotion). Sementara itu, untuk pemasaran jasa perlu bauran pemasaran yang diperluas (expanded marketing mix for service) dengan penambahan unsur non-tradisional marketing mix, yaitu manusia (people), proses (process) dan penampilan fisik (physical evidence) sehingga menjadi tujuh unsur. Kegiatan pemasaran merupakan suatu proses yang saling berhubungan sebagai suatu sistem (Jumilah ,2013).

Menurut Lupiyoadi dan Hamdani (2006) produk dalam pemasaran jasa merupakan keseluruhan konsep objek atau proses yang memberikan sejumlah nilai kepada konsumen. Menurut Elliot dan Cameron (1994) "other factors such as branding and product composition also play some role in consumers' choices". Artinya, faktor yang memengaruhi keputusan konsumen adalah branding dan komposisi produk. Konsumen dan produsen saat ini lebih mengutamakan produk-produk yang ramah lingkungan (Mayank dan Amit, 2013). Oleh karena itu, produk adalah bagian dari bauran pemasaran yang sangat penting. Menurut Zeithaml (1988), "Higher level abstraction rather than an attribute", hal ini berarti pendekatan dalam rangka menyampaikan informasi tentang produk akan selalu diingat oleh kosumen.

Menurut Tjiptono (2001), harga adalah hukum moneter yang dapat ditukarkan untuk mendapatkan hak atas suatu barang atau pemakaian layanan jasa. Dalam menentukan harga suatu produk atau jasa, ada beberapa dasar yang harus dipertimbangkan seperti tujuan perusahaan dalam memasarkan produk, strategi pemasaran, biaya produksi, biaya karyawan, metode yang dipakai, tujuan pasar, persaingan ataupun sasaran pasar.

Bagi perusahaan, penggunaan saluran distribusi adalah untuk meningkatkan efisiensi distribusi produk-produk perusahaan (Wuryanto, 2014). Saluran distribusi dapat didefinisikan sebagai saluran pemasaran atau saluran penjualan (Szopa dan Pekala, 2012). Menurut Warren (2003) lokasi distribusi adalah lokasi yang digunakan 
oleh produsen untuk menyalurkan barang dari produsen sampai ke konsumen atau pemakai industri. Dalam mementukan lokasi dstribusi, pihak manajeme haruslah mempertimbangkan secara cermat situasi dan beberapa faktor (Tjiptono, 2001), seperti; akses, visibilitas, ramai lalu lalang, kepadatan, lalu lintas, lahan parkir yang luas, ekspansi, lingkungan sekitar, kompetisi dan Peraturan pemerintah.

Kotler (2006) mengatakan bahwa unsur bauran promosi (promotion mix) terdiri atas lima perangkat utama, yaitu iklan (advertising), penjualan pribadi (personalselling), promosi penjualan (sales promotion), hubungan masyarakat dan publikasi (public relation and publication) dan pemasaran langsung (direct marketing). Promosi penjualan mencakup suatu variasi yang luas dari alat-alat promosi yang didesain untuk merangsang respon pasar yang lebih cepat atau lebih kuat (Natalia dan Mulyana, 2014).

Image perusahaan sangat bergantung kepada sikap dan perilaku orang-orang yang terlibat langsung (SDM) sehingga hal tersebut tentunya akan memengaruhi kualitas pelayanan yang ditawarkan. Dalam perusahaan jasa, hubungan antara karyawan dan konsumen memegang peran yang sangat penting dalam menciptakan nilai jasa.

Proses menurut Lupiyoadi dan Hamdani (2006) adalah gabungan semua aktivitas yang umumnya terdiri atas prosedur, jadwal pekerjaan, mekanisme, aktivitas, dan hal-hal rutin di mana jasa dihasilkan dan disampaikan kepada konsumen. Menurut Kotler (2002) definisi pelayanan adalah setiap tindakan atau kegiatan yang dapat ditawarkan oleh suatu pihak kepada pihak lain, yang pada dasarnya tidak berwujud dan tidak mengakibatkan kepemilikan apapun. Sekarang pelayanan online telah menjadi suatu solusi pelayanan yang cepat dan tepat sasaran. Menurut Yannopoulos (2011): "Internet-based technologies have significantly reduced the marginal cost of producing and distributing digital goods such as software, news stories, music, photographs, stock quotes, horoscopes, sports scores, and health tips" yang artinya teknologi internet yang berkembang sekarang mengurangi margin biaya dan prodiksi dari suatu proses produksi dan distribusi barang eletronik seperti perangkat lunak, persediaan, fotografi, berita, music, zodiac, olahraga dan kesehatan. Belanja lewat internet memudahkan konsumen, terutama pada saat liburan (Oh dan Kwon, 2009). Sistem layanan seperti ini bisa juga disebut dengan layanan elektronik (e-commerce/e-service). Menurut Desya (2012), layanan online atau e-service adalah istilah yang digunakan untuk layanan melalui internet. Efek dari e-commerce telah menyebar diberbagai area bisnis, dari pelayanan konsumen sampai ke desain produk (Gangeshwar, 2013). Macam-macam layanan online yang banyak dijumpai dan digunakan oleh konsumen, diantaranya adalah email, world wide web $(w w w)$, mailing list, chating, e-commerce, e-banking, e-government, dan e-learning.

Physical evidence atau penampilan fisik merupakan suatu hal yang secara nyata turut memengaruhi keputusan pelanggan, untuk membeli dan menggunakan produk jasa yang ditawarkan (Kotler, 2006). Pada perusahaan jasa, penampilan fisik lebih ditujukkan pada kenyamanan konsumen seperti kerapihan, kebersihan, kelengkapan, penampilan karyawan, kelancaran, dan lain sebagainya. Hal tersebut dilakukan dalam rangka memberikan kenyamanan dan kepuasan kepada konsumen.

Setiap orang pasti pernah mempertimbangkan sesuatu hal sebelum melakukan keputusan pembelian (Hariadi, 2013). Dalam suatu keputusan untuk melakukan pembelian, biasanya konsumen memutuskan mengenai produk dan jasa apa yang akan dibeli, tempat dilakukan pembelian, harga yang sesuai dan sebagainya (Lita, 2010). Pengetahuan konsumen memengaruhi minat belanja konsumen secara signifikan (Sarwar et al. 2013). Dalam proses mengolah informasi, terdapat empat tahap pembentukkan persepsi, yaitu tahap exposure, attention, comprehension, dan tahap retention. Persepsi konsumen menurut Robbins dalam Vaniia (2012) adalah proses dimana seseorang mengorganisir dan mengartikan kesan dari panca indera dalam tujuan untuk memberi arti dalam lingkungan mereka. Faktor-faktor penting dalam persepsi konsumen adalah accessibility, availability, quality, durability, regular support of product, dan mode of payment (Kazmi, 2012). Perilaku proses keputusan tidak berhenti pada tahap pembelian dan selanjutnya konsumen mengevaluasi, apakah pembelian yang dilakukan sesuai dengan apa yang diharapkan (Bardhani et al. 2009).

Waldi (2000) dengan judul "Analisis atribut produk dan promosi terhadap persepsi kualitas motor merek millenium (produk motor Cina)". Persamaan terhadap referensi ini adalah variabelnya sama-sama menggunakan variabel marketing mix, yaitu promosi. Perbedaannya terletak pada teknik analisis data. 
Peneliti menggunakan teknik analisis regresi (Uji t dan uji F). Rujukan berikutnya adalah penelitian dari Haryadi (2009) yang berjudul "Pengaruh strategi green marketing terhadap pilihan konsumen melalui pendekatan marketing mix Studi kasus pada The Body Shop Jakarta". Persamaan penelitian terhadap referensi ini adalah variabel yang dipakai sedangkan perbedaannya adalah variabel yang gunakan peneliti adalah lokasi distribusi, promosi dan layanan online serta faktor yang dianalisis.

\section{METODE}

Penelitian ini bersifat explanatorystudy, yaitu penelitian yang bertujuan menelaah kausalitas antar variabel dan menjelaskan suatu fenomena tertentu. Penelitian eksplanatif menggunakan pengujian hipotesis berupa statistik inferensial. Berdasarkan penelitian yang menjelaskan dan menguji hipotesis, penelitian ini menggunakan pendekatan kuantitatif dengan memakai deskriptif statistik inferensial.

Penelitian ini dilaksanakan di kantor PT. Home Cedit Indonesia di empat gerai yang berada di daerah Jakarta Selatan. Penelitian di mulai dari Juli 2016 sampai Agustus 2016. Populasi penelitianini adalah pengunjung PT. Home Credit Indonesia. Teknik pengambilan sampel yang digunakan adalah quota sampling dan incidental sampling mengingat responden yang relevan diambil berada pada empat lokasi di Jakarta Selatan. Setelah masing-masing gerai di proporsikan kuota pengunjungnya karena jumlah pengunjung tiap gerai berbeda-beda, peneliti melanjutkan dengan pengambilan sampel incidental sampling. Pengambilan sampel dari populasi secara acak berdasarkan frekuensi probabilitas semua anggota populasi. Jumlah sampel penelitian ini adalah 110 responden.

Penelitian ini dilaksanakan di kantor PT. Home Cedit Indonesia di empat gerai yang berada di daerah Jakarta Selatan. Penelitian di mulai dari Juli 2016 sampai Agustus 2016. Informasi dihimpun melalui kuesioner yang kuesioner skala Likert. Selanjutnya peneliti melakukan uji asumsi berupa uji normalitas, multikolinieritas dan heteroskedastisitas. Untuk pengujian hipotesis menggunakan analisis deskriptif sedangkan untuk mengukur dan menentukan hubungan sebab - akibat (kausal) antara satu variabel dan variabelvariabel lainnya, uji hipotesis dilakukan dengan analisis regresi (Uji t dan Uji F). Model analisis regresi berganda dirumuskan dengan persamaan berikut:

$$
\mathrm{Y}=\underset{\mathrm{b}_{7} \mathrm{X}_{7}}{\mathrm{a}+\mathrm{b}_{1} \mathrm{X}_{1}+\mathrm{b}_{2} \mathrm{X}_{2}+\mathrm{b}_{3} \mathrm{X}_{3}+\mathrm{b}_{4} \mathrm{X}_{4}+\mathrm{b}_{5} \mathrm{X}_{5}+\mathrm{b}_{6} \mathrm{X}_{6}+}
$$

Keterangan: Y (variabel dependen (terikat); perilaku konsumen); X (variabel independen (bebas); X1(Produk); X2 (Harga); X3 (Lokasi); X4 (Promosi); X5 (Manusia); X6 (Pelayanan); X7 (Kenyamanan).

Untuk mengetahui apakah hasil regresi sudah benar, maka uji kelayakan perlu dilakukan. Pengujian model dapat dilakukan dengan menggunakan nilai $F$ atau dengan menggunakan nilai probabilitas atau nilai sig dalam tabel ANOVA. Untuk dapat mengukur tingkat kesesuaian model penelitian dapat menggunakan the goodness of an econometrical model, yaitu model yang memiliki karakteristik kelayakan untuk penelitian dengan forecasting ability, yaitu karakteristik model dapat digunakan untuk mengetahui kemempuan memprediksi keadaan di masa yang akan datang (koefisien determinasi $\mathrm{R}^{2}>0,5$ ). Semua pengolahan data dilakukan dengan software SPSS 17.0.

Variabel dependen penelitian ini adalah persepsi konsumen yang melingkupi menggunakan jasa Home Credit dan merekomendasikan. Variabel independennya $(\mathrm{X})$ berupa bauran pemasaran. Elemen bauran pemasaran berupa produk, harga, lokasi, promosi, SDM, pelayanan dan kenyamanan. Variabel produk (X1) terdiri dari intangibility, inseparability, variability,perishability. Variabel harga (X2) terdiri dari harga produk, harga discount, harga cicilan, biaya administrasi dan biaya lain-lain. Untuk variabel lokasi (X3) mencakup akses, visibilitas, lalu lintas, lahan parkir yang luas, lingkungan sekitar. Variabel promosi (X4) terdiri dari iklan dan sales promotion. Variabel sumber daya manusia (X5) terdiri dari pengetahuan produk oleh karyawan, keramahan karyawan dan pelayanan karyawan. Untuk variabel proses/pelayanan (X6) mencakup layanan online, mekanisme dan informasi dan layanan pasca pembelian. Sedangkan (X7) penampilan fisik/kenyamanan melingkupi penampilan karyawan, kebersihan lokasi dan keamanan. 


\section{HASIL}

\section{Uji Validitas dan Realibilitas}

Dengan jumlah sampel 110 orang maka derajat bebasnya adalan $\mathrm{N}-2$ atau 108 sehingga didapatkan data r-tabelnya 0,187 . Diketahui nilai r-hitung dengan menggunakan Bivariate Pearson pada setiap sub variabel lebih besar dari 0,187 sehingga dapat dikatakan bahwa sub variabel dalam kuesioner sudah valid.

Dari hasil output data dengan menggunakan SPSS, dihasilkan nilai Cronbach's Alpha, jika dibandingkan, lebih besar dari rtabel (rtabel $=0.187$ ). Hal ini mengidentifikasikan bahwa item data yang digunakan untuk penelitian adalah reliabel dan dapat digunakan.

\section{Uji Asumsi}

Hasil uji normalitas dengan Kolmogorov-Smirnov, didapatkan data KZS dan nilai sig lebih besar dari alpha 5\%. Kriteria keputusan mengikuti sebaran normal jika nilai sig. lebih besar dari alpha 5\%. Maka dapat disimpulkan bahwa data terdistribusi normal. Pada uji multikolinearitas, diketahui bahwa nilai VIF untuk semua variabel lebih kecil dari 10 dan toleransinya juga lebih besar dari 0,1. Artinya, tidak ada multikolinearitas pada analisis regresi sehingga memenuhi asumsi analisis regresi berganda.

Pada Gambar 2 adalah gambar output dari uji heteroskedastisitas antara nilai dugaan dengan sisaan, terlihat titik pada sumbu menyebar secara rata dan tidak membentuk pola tertentu. Oleh karena itu, dapat disimpulkan bahwa tidak terjadi heteroskedasitas pada analisis regresi berganda.

\section{Pengujian Hipotesis Statistik}

Berdasarkan pengolahan data melalui SPSS 17.0, diketahui pada Tabel ANOVA nilai sig $=0.000$ lebih kecil dari alpha 5\% maka tolak H0 artinya secara keseluruhan model regresi berpengaruh atau minimal ada satu variabel dari faktor bauran pemasaran yang berpengaruh signifikan terhadap persepsi konsumen. Dari output yang keluar terlihat bahwa F-hitung = 14,454 dengan tingkat signifikansi atau probabilitas 0,00 $<0,05$ maka regresi dapat dipakai untuk memprediksi persepsi konsumen. Untuk uji t, berdasarkan tabel 12 maka dapat dibuat persamaan regresi berganda sebagai berikut:

$$
\begin{aligned}
\mathrm{Y}= & 7,91+0,098 \mathrm{X} 1-0,016 \mathrm{X} 2+0,434 \mathrm{X} 3-0,251 \mathrm{X} 4- \\
& 0,286 \mathrm{X} 5+0,504 \mathrm{X} 6+1,574 \mathrm{X} 7
\end{aligned}
$$

Nilai sig dari setiap variabel. Variabel produk, harga, promosi, SDM dan pelayanan memiliki nilai sig yang di atas alpha 5\% masing-masing, yaitu 0,$544 ; 0,935$, 0,354; 0,336; dan 0,078. Uji-t untuk kelima variabel ini adalah terima $\mathrm{H} 0$ artinya produk, harga, promosi, SDM dan pelayanan tidak berpengaruh terhadap persepsi konsumen. Sedangkan untuk variabel lainnya yaitu lokasi dan kenyamanan memiliki nilai sig yang lebih kecil dari alpha 5\% sehingga variabel tersebut secara signifikan berpengaruh terhadap respon persepsi konsumen.

Untuk uji kebaikan model, dari output diketahui nilai $\mathrm{R}$-square $=0,464$ atau $46,4 \%$ artinya keragaman persepsi konsumen mampu dijelaskan oleh faktor bauran pemasaran sebesar $46,4 \%$ sedangkan sisanya $53,6 \%$ dipengaruhi oleh faktor lain yang diluar model.

\section{1) Pengaruh produk terhadap persepsi konsumen}

Hasil olah data dengan uji-t, maka output pengolahan data adalah nilai sig untuk variabel produk adalah $54,4 \%$ yaitu lebih besar dari nilai alpha 5\%. Hal ini mengidentifikasi bahwa persepsi produk yang ditawarkan berupa produk yang bermerek, produk yang variatif, berkualitas tinggi, prosesnya yang cepat, program kredit yang bayak dan kemudahan proses tidak berpengaruh signifikan terhadap persepsi konsumen memilih PT. Home Credit Indonesia untuk pembiayaan kebutuhannya. Keragaman persepsi konsumen yang mampu dijelaskan oleh variabel produk hanya $54,4 \%$ saja. Hal tersebut menunjukkan bahwa masih ada beberapa hal yang dipengaruhi oleh faktor-faktor lainnya di luar model sebesar $45,6 \%$.

Gaya hidup masyarakat yang semakin kompleks merupakan sebuah peluang yang dapat dilirik oleh setiap perusahaan, yaitu dengan menawarkan berbagai jenis produk yang bermutu dan kompetitif (Pratiwi dan Sudiksa (2013). Variabel produk ini sendiri sebenarnya merupakan suatu representasi dari perusahaan yang terdiri dari produk barang dan produk jasa yang ditawarkan. Umumnya konsumen tidak hanya melihat suatu produk hanya dari satu sisi saja, akan tetapi secara multidimensi nilai dari kualitas produk itu sendiri (Rahman, 2011). Perusahaan tidak perlu memperbaiki kualitas produk berupa barang secara menyeluruh 
karena biasanya konsumenlah yang memilih sendiri produk barang yang dibutuhkan. Setelah konsumen menentukan produk barang, barulah konsumen memilih produk jasa untuk proses pembiayaan. Dalam hal ini, jasa masih merupakan produk yang utama yang ditawarkan oleh PT. Home Credit Indonesia.

Hal tersebut merupakan penyebab variabel produk tidak berpengaruh signifikan terhadap persepsi konsumen. Konsumen merasa bahwa produk berupa barang yang ditawarkan sifatnya hanya sebatas penawaran saja. Konsumen tidak harus memilih produk barang yang ditawarkan perusahaan, akan tetapi konsumen hanya memerlukan jasa pembiayaannya saja. Untuk aneka penawaran program dan proses dirasa konsumen masih sama dan standar penawarannya dibandingkan dengan kompetitor lainnya.

\section{2) Pengaruh harga terhadap persepsi konsumen}

Pengolahan data dengan menggunakan uji-t untuk mengetahui persepsi harga-harga seperti harga tiket masuk, tiket ontang-anting, biaya parkir kendaraan roda dua atau roda empat, harga harga yang kompetitif, discount harga merek tertentu, cicilan $0 \%$ dan bebas biaya administrasi ternya tidak berpengaruh signifikan terhadap persepsi konsumen. Hal ini dapat diketahui berdasarkan nilai sig untuk variabel harga, yaitu 93,5\% atau dapat dikatakan lebih kecil dari nilai alpha 5\% sehingga besar keragaman persepsi konsumen yang mampu dijelaskan oleh variabel harga sebesar 93,5\% sisanya $6,5 \%$ terindikasi dipengaruhi oleh faktor-faktor lain di luar model.

Harga merupakan salah satu hal penting dalam menarik minat konsumen, akan tetapi harga yang ditawarkan tidak terlalu responsif terhadap persepsi konsumen. Setiap konsumen kurang peduli dengan harga yang kompetitif yang ditawarkan perusahaan. Konsumen mengekspektasikan harga yang kompetitif sehingga mereka tertarik untuk menggunakan jasa PT Home Credit Indonesia, akan tetapi pada realitanya semua harga yang ditawarkan dirasa masih kurang kompetitif oleh para konsumen. Begitu juga dengan discount merek tertentu dan program cicilan $0 \%$. Kompetitor banyak yang menawarkan program yang sama sehingga konsumen mengekspektasikan hal tersebut sebagai penawaran harga yang biasa saja.

\section{3) Pengaruh lokasi terhadap persepsi konsumen}

Hasil pengolahan data dengan menggunakan uji-t, maka diketahui bahwa nilai sig untuk variabel tempat adalah 2,3\%, yaitu lebih kecil dari nilai alpha 5\%. Hal tersebut menunjukkan bahwa persepsi variabel lokasi yang mencakup kemudahan akses, strategis, kemudahan transportasi, keluasan lahan parkir dan ramai dikunjungi ternyata berpengaruh signifikan terhadap persepsi konsumen.

Seiring dengan pertambahan jumlah populasi, maka akan berpengaruh terhadap jumlah toko kebutuhan sehari-hari (Andreti et al. 2013). PT Home Credit juga telah melakukan ekspansi lokasi baru dalam periode tahun 2015. Hal yang menjadi pertimbangan utama terkait tempat terletak pada strategis, kemudahan akses menuju lokasi dan kemudahan transportasi menuju lokasi. Tujuan akhir sebuah perusahaan adalah agar produknya bisa diterima oleh konsumen (Supariyani dan Djakaria, 2010). Apalagi jika lokasi memiliki lahan parkir yang luas dan ramai dikunjungi. Konsumen yang memang berniat untuk melakukan transaksi pembiayaan ini, mencari kemudahan dalam menuju lokasi. Konsumen pergi ke lokasi karena ingin melihat kondisi produk dan menerima informasi secara langsung dari karyawan tentang proses kredit. Oleh karena itu, konsumen memilih lokasi yang mudah untuk didatangi. Tingkat strategis dan kemudahan akses transportasi umum sangat penting dalam menarik minat konsumen datang ke lokasi. Untuk yang mempunyai mobil, lahan parkir merupakan salah satu hal yang sangat vital karena dengan keluasan lahan parkir, konsumen merasa aman dan nyaman di lokasi. Kesalahan dalam memilih saluran distribusi dapat berpengaruh dan menghambat kepada kelancaran proses penyaluran dari produsen ke konsumen (Ningrum, 2012).

4) Pengaruh promosi terhadap persepsi konsumen

Untuk hasil pengolahan data dengan menggunakan uji-t, diketahui bahwa persepsi promosi yang meliputi iklan, pemberian souvenir, promosi pembelian dan kesesuaian promosi tidak berpengaruh signifikan terhadap persepsi konsumen. Hal ini dapat diketahui berdasarkan nilai sig untuk variabel promosi yaitu $35,4 \%$ atau dapat dikatakan lebih besar dari nilai alpha $5 \%$. Besar keragaman persepsi konsumen yang mampu dijelaskan oleh variabel promosi sebesar $35,4 \%$ sisanya $64,6 \%$ terindikasi dipengaruhi oleh faktor-faktor lain di luar model. 
Promosi akan kualitas produk yang ditawarkan dengan harga murah didukung fasilitas juga menjadi modal utama untuk menarik minat konsumen (Tan, 2011). Pihak perusahaan telah melakukan promosi yang cukup gencar baik itu melalui promosi offline maupun online. PT. Home Credit Indonesia harus menggencarkan iklannya agar konsumen dapat selalu mendapatkan informasi tentang promosi yang ditawarkan oleh perusahaan. Realisasi iklan dan pemberian souvenir yang dirasa telah sesuai dalam rangka untuk memanjakan konsumen, hal itu ternyata tidak berpengaruh terhadap persepsi konsumen. Konsumen merasa segala promosi yang dilakukan oleh perusahaan merupakan suatu hal yang sudah bisa dilakukan oleh perusahaan lain yang sejenis. Berbagai penawaran kredit biasanya sama oleh competitor biasanya sama atau berkisar antara cicilan ringan, kemudahan proses ataupun penjualan dengan discount. Konsumen ingin mendapatkan sesuatu yang special atau lebih dari janji promosi yang diberikan.

\section{5) Pengaruh SDM terhadap persepsi konsumen}

Hasil pengolahan data diketahui bahwa variabel sumber daya manusia tidak berpengaruh terhadap persepsi konsumen. Hasil penelitian ini menunjukkan bahwa kualitas SDM yang dimiliki perusahaan yang mencakup penguasaan produk, keramahan dan service excellent karyawan tidak berpengaruh terhadap persepsi konsumen. Hal ini dapat diketahui berdasarkan nilai sig untuk variabel manusia masih lebih besar dari nilai alpha 5\%, yaitu $33,6 \%$.

Dalam perusahaan yang bergerak dibidang jasa, pengetahuan, keramahan dan pelayanan karyawan merupakan hal yang harus terstandarisasi. Hal tersebut penting karena dapat membangun komunikasi, menyampaikan informasi dan meraih kepercayaan pengunjung, dan dari hasil penelitian hal tersebut memengaruhi keputusan pengunjung secara signifikan. Dari data yang telah diolah, diperoleh bahwa SDM tidak berpengaruh terhadap persepsi konsumen. Sebagian besar konsumen datang ke lokasi maupun berinteraksi seacara online untuk mendapatkan informasi ataupun pelayanan, untuk itu peran dari sumberdaya manusia di sangat penting untuk menjalin komunikasi dan memberikan informasi kepada konsumen agar tidak terjadi kesalahpahaman ataupun ketidakpuasan. Akan tetapi menurut ekspektasi konsumen, hal tersebut merupakan salah satu pelayanan yang mereka dapat dalam bertransaksi. Ada faktor lain yang menjadi kepentingan konsumen dalam memilih PT Home Credit Indonesia menjadi pilihan konsumen dalam pembiayaan kebutuhannya. Hal ini menjelaskan kenapa variabel SDM tidak memengaruhi keputusan pengunjung.

\section{6) Pengaruh pelayanan terhadap persepsi konsumen}

Hasil pengolahan data dengan menggunakan uji-t, diketahui nilai sig untuk variabel pelayanan adalah $7,8 \%$ yaitu lebih besar dari nilai alpha 5\%. Hal tersebut menunjukkan bahwa variabel pelayanan yang mencakup pengajuan aplikasi online, kemudahan prosedur aplikasi dan contact center tidak berpengaruh terhadap persepsi konsumen.

Semua pihak yang membeli dan mengkonsumsi jasa perbankan akan memberikan penilaian yang berbedabeda terhadap kualitas Iayanan (Hidayat, 2009). Perusahaan harus mulai mernikirkan pentingnya program pelayanan pelanggan secara lebih matang melalui kualitas pelayanan (Utama, 2003). Sekarang ini informasi secara online telah dilakukan oleh perusahaan-perusahaan dan dipercaya bahwa sebagian konsumen paham dan dapat membaca informasi yang ada di website. PT. Home Credit Indonesia telah mengembangkan sistem pengajuan aplikasi dengan melalui internet sehingga memudahkan konsumen dalam pengajuan prosedur aplikasi. Selain itu contact center juga dibangun dalam rangka untuk menjadi perantara antara konsumen dan perusahaan. Akan tetapi, hal tersebut belum cukup memengaruhi persepsi konsumen. Konsumen berpresespri bahwa hal tersebut merupakan suatu satu kesatuan pelayanan yang wajib dimiliki perusahaan jasa. Konsumen mengespektasikan lebih dari sistem online dan contact center. Kondisi ini menjelaskan kenapa variabel pelayanan tidak berpengaruh signifikan terhadap persepsi konsumen.

7) Pengaruh kenyamanan terhadap persepsi konsumen

Untuk hasil pengolahan data dengan menggunakan uji-t maka diketahui bahwa nilai sig untuk variabel kenyamanan adalah $0 \%$, yaitu lebih kecil dari nilai alpha $5 \%$. Hal tersebut menunjukkan bahwa kenyamanan yang mencakup penampilan karyawan, kebersihan dan kenyamanan lokasi relatif berpengaruh terhadap persepsi konsumen. 
Pada perusahaan yang menjual jasa, penampilan dari karyawan maupun kondisi fisik lokasi merupakan hal yang penting karena variabel ini secara langsung memengaruhi reputasi perusahaan. Kebersihan dan kenyamanan adalah hal yang mutlak diperlukan dalam pengelolaan kondisi lokasi karena hal tersebut sangat memengaruhi kenyamanan konsumen dalam mendapatkan pengalaman belanja. Begitu juga dengan penampilan karyawan merupakan nilai tambah tersendiri untuk konsumen. Hasil penelitian, konsumen merasa hal tersebut sangatlah penting dan berpengaruh terhadap persepsi mereka untuk memilih PT. Home Credit Indonesia sebagai perusahaan pembiayaan. Hal ini berarti kenyamanan adalah hal yang mutlak dianggap penting oleh konsumen. Konsumen berpendapat bahwa hal tersebut merupakan nilai tambah tersendiri agar mereka dapat memutuskan untuk bertransaksi lewat PT. Home Credit Indonesia. Melihat kondisi tersebut, dapat menjelaskan kenapa variabel kenyamanan berpengaruh signifikan terhadap persepsi konsumen. Berdasarkan hasil penelitian, bauran pemasaran yang sesuai untuk PT. Home Credit Indonesia adalah variabel yang terpengaruh terhadap persepsi konsumen, yaitu lokasi, pelayanan, dan kenyamanan.

\section{Implikasi Manajerial}

Berdasarkan penelitian terhadap hubungan antara variabel bauran pemasaran terhadap persepsi konsumen terhadap PT. Home Credit Indonesia, perlu ditekankan pentingnya memberikan prioritas terhadap aspek yang berkaitan dengan pengembangan perusahaan terutama variabel tempat, pelayanan dan kenyamanan. Beberapa hal yang dapat menjadi prioritas pihak manajemen dalam pengembangan dan pembuatan strategi pemasaran yang berhubungan dengan variabel tempat atau lokasi adalah dengan memperbanyak lokasi pemasaran dan kerjasama dengan toko elektronik atau toko kebutuhan konsumen. Pengembangan variabel pelayanan dapat dilakukan dengann mengadakan pelayanan jemput bola pasca penggunaan jasa dan mengembangnakn saluran pelayanan melalui media sosial. Pada variabel kenyamanan, perusahaan dapat memberlakukan kepada karyawannya kewajiban menggunakan greeting dan pemakaian seragam yang unik serta penyediaan snack atau minuman ringan untuk konsumen yang datang.

\section{KESIMPULAN DAN SARAN}

\section{Kesimpulan}

Tidak semua variabel bauran pemasaran berpengaruh terhadap persepsi konsumen. Dari semua variabel bauran pemasaran, yang memengaruhi persepsi konsumen adalah variabel lokasi, pelayanan dan kenyamanan.

Ketiga variabel berpengaruh ini dirujuk dalam rangka memudahkan konsumen dan peningkatan kepuasan dan kenyamanan perusahaan. Untuk variabel produk, harga, SDM dan promosi tidak cukup memengaruhi persepsi konsumen akan tetapi variabel-variabel tersebut tetap penting dan harus ditingkatkan.

Komponen bauran pemasaran yang telah dilakukan PT. Home Credit Indonesia dirasa cukup efektif pelaksanaannya, akan tetapi melihat jumlah konsumen yang bertambah setiap tahun maka pergeseran tujuan pemasaran dari akuisisi pembeli (customer acquisition) kepada kesetiaan pelanggan (customer retention or customer loyalty) harus segera dilakukan. Motivasi dari konsumen adalah untuk mendapatkan bantuan pembiayaan yang cepat, tepat dan mudah. Jika motivasi tersebut terpenuhi, maka akan berpengaruh terhadap persepsi konsumen untuk dapat memilih PT. Home Credit Indonesia untuk membiayai konsumsi kredit mereka. Sampel penelitian berfokus pada konsumen yang berkunjung ke lokasi PT. Home Credit Indonesia. Oleh karena itu, hasil penelitian ini dapat digeneralisasikan untuk semua lokasi PT. Home Credit Indonesia di Indonesia, dan diharapkan hasil penelitian ini dapat dijadikan sebagai referensi dan masukkan bagi semua pihak.

\section{Saran}

Bagi perusahaan diharapkan dapat mempertahankan variabel-variabel bauran pemasaran yang telah sesuai dengan persepsi konsumen yang dalam hal ini variabel lokasi dan promosi yang merupakan variabel yang secara signifikan memengaruhi. Selain itu, perusahaan sebaiknya juga memperbaiki variabelvariabel bauran pemasaran yang meskipun tidak cukup memengaruhi persepsi konsumen, tetapi cukup penting dalam kolaborasi pemasaran dan penentuan strategi pemasaran perusahaan. Variabel tersebut meliputi produk, harga, SDM, promosi dan pelayanan. Variabel tersebut tetap harus dikembangkan seiring 
dengan meningkatnya ekspektasi konsumen terhadap perusahaan jasa pembiayaan. Perusahaan dapat memenuhi kriteria implikasi manajemen per variabel yang diajukan, meliputi; memperbanyak lokasi pemasaran, kerjasama dengan toko elektronik atau toko kebutuhan konsumen, kewajiban mengucapkan "greetings" oleh karyawan, seragam yang unik serta penyediaan snack dan minuman ringan. Perusahaan dapat melakukan studi banding dengan kompetitor atau perusahaan sejenis untuk mencari benchmark terhadap bauran pemasaran untuk memperoleh informasi dan menambah pengetahuan tentang bauran pemasaran yang dilakukan oleh perusahaan pembiayaan lain.

Penelitian selanjutnya dapat dilakukan dengan melanjutkan meneliti seputaran pengaruh variabelvariabel bauran pemasaran dengan persepsi konsumen setelah dilakukan perbaikan. Selain itu peneliti dapat meneliti variabel-variabel bauran pemasaran untuk perusahaan lain yang sejenis. Penelitian selanjutnya dapat meneliti lebih mendalam pengaruh variabelvariabel bauran pemasaran terhadap kepuasan ataupun loyalitas konsumen.

\section{DAFTAR PUSTAKA}

Andreti J, Zhafira NH, Akmal SS, Kumar S. 2013. The analysis of product, price, place, promotion and service quality on customers' buying decision of convenience store: a survey of young adult in bekasi, West Java. Indonesia International Journal of Advance in Management and Economics 2(6): 72-78.

Bardhani MA, Zakaria FR, Palupi NS. 2009. Analisis persepsi konsumen terhadap produk minyak sawit merah sebagai minyak kesehatan (studi kasus: perumahan Ciomas Permai, Bogor). Manajemen IKM 4(2): 185-194.

Changchit C. 2006. Consumer perceptions of online shopping. Information System 7(2): 177-181.

Desya. 2012. Layanan online. http://mazayadesya. blogspot.co.id/2012/09/layanan-online.html [7 September 2016].

Elliot GR, Cameron RC. 2013. Consumer perception of product quality and the country of origin effect. Journal of International Marketing 2(2): 49-62.

Gangeshwer DK. 2013. E-Commerce or internet marketing: a business review from Indian context. International Journal of $U$ - and $e$ Service, Science and Technology 6(6): 187-194. https://doi.org/10.14257/ijunesst.2013.6.6.17.

Hariadi D. 2013. Pengaruh produk, harga, promosi dan distribusi terhadap keputusan pembelian konsumen pada produk projector microvision. Jurnal Ilmu dan Riset Manajemen 1(1): 67-87.

Hariyadi R. 2009. Pengaruh strategi green marketing terhadap pilihan konsumen melalui pendekatan marketing mix (studi kasus The Body Shop Jakarta) [tesis]. Jakarta: Universitas Diponegoro.

Heryanto I. 2015. Analisis pengaruh produk, harga, distribusi dan promosi terhadap keputusan pembelian serta implikasinya pada keputusan pelanggan. Jurnal Ekonomi, Bisnis dan Enterpreneurship 9(2): 80-101.

Hidayat R. 2009. Pengaruh kualitas layanan, kualitas produk dan nilai nasabah terhadap kepuasan dan loyalitas nasabah bank mandiri. Jurnal Manajemen dan Kewirausahaan 11(1): 59-72.

[Home Credit Indonesia] Home Credit Indonesia. 2014. Laporan Keuangan 2015. Jakarta: PT Home Credit Indonesia.

Jumilah. 2013. Persepsi konsumen tentang produk, harga dan saluran distribusi serta pengaruhnya terhadap keputusan pembelian reseller. Jurnal Ilmu dan Riset Manajemen 1(1): 105-118.

Kazmi SQ. 2012. Consumer perceptions and buying decisions (the pasta study). International Journal of Advancement in Research and Technology 1(6): 1-10.

Kotler P. 2006. Principles of Marketing. 10th ed. New Jersey: Prentice Hall Upper Sadle River.

Lita RP. 2010. Pengaruh implementasi bauran pemasaran jasa terhadap proses keputusan wisatawan mengunjungi obyek wisata di kota padang. Jurnal Doktor Ilmu Manajemen Universitas Andalas 2(2): 91-99.

Lupiyoadi, Hamdani. 2006. Manajemen Pemasaran Jasa. Ed ke-2. Jakarta: Salemba Empat.

Mayank B, Amit J. 2013. Green marketing: a study of consumer perception and preference in India. Electronic Green Journal 1(36): 1-19.

Natalia P, Mulyana M. 2014. Pengaruh periklanan dan promosi terhadap keputusan pembelian. Jurnal Ilmiah Manajemen Kesatuan 2(2): 119-128.

Nurani, Wuryanto T. 2014. Analisis saluran distribusi selektif agen dan sub agen terhadap volume penjualan. Jurnal Universitas Tulungagung 1(2): 23-33.

Oh H, Kwon KN. 2009. Emerals article : an explanatory study of sales promotion for multichannel 
holiday shopping. International Journal of Retail and Distribution Management 37(10): 867-887. https://doi.org/10.1108/09590550910988048.

Szopa P, Pekala W. 2012. Distribution channels and their roles in the enterprise. polish Journal of Management Studies 6: 143-150.

Pratiwi PAOA, Sudiksa IB. 2013. Pengaruh marketing mix terhadap keputusan konsumen dalam pembelian mobil toyota avanza pada pt. agung automall denpasar. Jurnal FE Udayana 2(9): 1053-1070.

Putri SE. 2011. Persepsi konsumen terhadap bauran promosi (promotional mix) pada matahari departement store Bengkulu. Polish Journal of Management Studies. 6: 143-150.

Rahayu I, Nurrochmat D, Fachrodji A. 2015. Marketing mix analysis of natural tourism area 'kawah putih' and its effect on visitors' decision. Indonesian Journal of Business and Entrepreneurship 1(2): 72-80. doi:http://dx.doi.org/10.17358/ ijbe.1.2.72

Rahman O. 2011.Understanding consumer's perception and behaviours: implications for denim jeans design. Journal of Textile and Apparel Technology and Management 7(1): 1-16.

Sarwar A, Asam SMF, Haque A, Sleman G, Rajab S. 2013. Consumer's perceptions toward buying Chinese products: an empirical investigation in Malaysia. World Applied Science Journal 22(2): 152-160.
Suparyani E, Djakaria A. 2010. Pengaruh jumlah saluran distribusi terhadap omzet penjualan (studi kasus pada pt. heinz ABC Indonesia cabang Bogor). Jurnal Ilmiah Ranggagading 10(2): 95-102.

Tan ER. 2011. Pengaruh faktor harga, promosi dan pelayanan terhadap keputusan konsumen untuk belanja di alfamart surabaya. Jurnal Kewirausahaan 5(2): 25-40.

Tjiptono F. 2001. Strategi Pemasaran. Ed ke-1. Yogyakarta: Andi Ofset.

Tjiptono F, Gregorius C. 2012. Pemasaran Strategik. Ed ke-2. Yogyakarta: Andi Offset.

Utama A. 2003. Analisis pengaruh persepsi kualitas pelayanan terhadap kepuasan pelanggan rumah sakit umum cakra husada Klaten. OPSI 1(2): 96110.

Vaniia. 2012. Persepsi konsumen. http://vaniariyanti. blogspot.co.id/2012/05/persepsi-konsumenpengertian-persepsi.html [18 Juli 2016].

Waldi DA. 2000. Analisis pengaruh atribut produk dan promosi terhadap persepsi kualitas motor merek Millenium (produk motor Cina) [tesis]. Jakarta: Universitas Diponegoro.

Warren JK. 2003. Manajemen Pemasaran Global. Jakarta: PT Indeks Gramedia.

Yannopoulos. 2011. Impact of the internet marketing strategy formulation. International Journal of Business and Socil Science 2(18): 1-7.

Zeithaml CA. 1998. Consumer perceptions of price, quality and value: a means end model and synthesis of evidence. Journal of Marketing 52(3): 2-22. https://doi.org/10.2307/1251446. 